\title{
Live-live and live-dead interactions in marine death assemblages: The case of the Patagonian clam Venus antiqua
}

\author{
Sandra Gordillo and Fernando Archuby \\ Acta Palaeontologica Polonica 59 (2), 2014: 429-442 doi: http://dx.doi.org/10.4202/app.2011.0176
}

In this work we studied bioerosion and encrustation on dead shells of the shallow benthic clam Venus antiqua from Patagonia Argentina with the aim of understanding biotic interactions (live/live interaction) and postmortem encrustation (live/dead interaction). In this regard, drill hole analysis and epibiont distribution in shells from modern death assemblages were performed. Additionally, we analyzed crushing traces in the shells of the drilling gastropod Trophon geversianus, which were caused by another predator. The analysis of drill hole placement and epibiont distribution on V. antiqua shells show drill holes (75\%) and the epibiont Crepidula spp. (70.91\%) more concentrated in the upper sector of the valve, which might be explained by the vertical position and a semi-infaunal mode of life in this clam. Nevertheless, the presence of drill holes in the lower sector of the valve indicates that clams spent part of the time reclining on the sediment. There is also evidence that clams with Crepidula spp. as commensals are less frequently attacked by drilling gastropods. Besides, a high percentage of articulated clams (30.97\%) show signs of attack by drilling gastropods, but incomplete drill holes (7.67\%) also suggest failed attempts, resulting in a minimum of $23.30 \%$ of successful predation. These incomplete drill holes may suggest failed attempts due to another predator attack upon the snails consuming the clams thus interrupting the feeding activity: more than $60 \%$ of marks of crushing in T. geversianus shells could have been produced by other predators, such as crabs. The postmortem encrustation on V. antiqua shells (35\%) was mainly produced by calcareous polychaetes, preferably located on the inner side of the valve indicating that the empty shells of $V$. antiqua served as cryptic environment before they become exposed on the beach. Finally our data show that drilling frequency is very low in Pleistocene assemblages, suggesting changes in burial depth dynamics of this suspension feeder.

Key words: Mollusca, Bivalvia, biotic interactions, drilling predation, crushing, epibionts, postmortem encrustation, Recent, Pleistocene, Patagonia.

Sandra Gordillo [sgordillo@ cicterra-conicet.gov.ar], Centro de Investigaciones en Ciencias de la Tierra, Consejo Nacional de Investigaciones Científicas y Técnicas (CICTERRA, CONICET); Centro de Investigaciones Paleobiológicas (CIPAL), Facultad de Ciencias Exactas, Físicas y Naturales, Universidad Nacional de Córdoba. Av. Vélez Sársfield 1611 X5016GCA Córdoba, Argentina; Fernando 
Archuby [farchuby@ unrn.edu.ar], Instituto de Paleobiología y Geología, Universidad Nacional de Río Negro, Av. Roca 1242, General Roca, Río Negro, Argentina.

This is an open-access article distributed under the terms of the Creative Commons

Attribution License (for details please see creativecommons.org), which permits unrestricted use, distribution, and reproduction in any medium, provided the original author and source are credited.

Fof Full text $(570.7 \mathrm{kB})$ 